\title{
Penerapan Model Pembelajaran Mastery Laerning Melalui Gabungan Supervisi Individual dan Supervisi Akademik Dibantu dengan Supervisi Manajerial Sebagai Upaya Meningkatkan Kemampuan Guru
}

\section{Wayan Jiwa*}

SD Negeri 1 Serongga

\section{A R T I C L E I N F O}

\section{Article history:}

Received 19 August 2019

Received in revised form

30 September 20189

Accepted 10 October 2019

Available online 29

November 2019

\section{Kata Kunci:}

Supervisi Akademik dan Supervisi Manajerial,

Mastery Learning.

Keywords:

Academic Supervision and

Managerial Supervision,

Mastery Learning
A B S T R A K

Penelitian ini dilaksanakan di SD Negeri 1 Serongga Kecamatan Gianyar. Tujuan penulisan penelitian tindakan sekolah ini adalah untuk mengetahui apakah supervisi akademik dan supervisi manajerial dapat meningkatkan kemampuan guru SD Negeri 1 Serongga, dalam melaksanakan proses pembelajaran menggunakan model Mastery Learning. Metode pengumpulan datanya adalah observasi. Metode analisis datanya adalah deskriptif untuk data kuantitatif. Hasil yang diperoleh dari penelitian ini adalah bahwa supervisi klinik dapat meningkatkan kemampuan guru-guru dalam melaksanakan proses pembelajaran menggunakan model pembelajaran Mastery Learning Ini terbukti dari hasil yang diperoleh pada Siklus I meningkat rata-ratanya menjadi 80,00 dari data awal dan pada Siklus II naik rata-ratanya menjadi 87,1 dari Siklus I.Kesimpulan yang diperoleh dari penelitian ini adalah supervisi akademik dan supervisi manajerial dapat meningkatkan kemampuan guru-guru dalam melaksanakan proses pembelajaran menggunakan model pembelajaran Mastery Laerning.

\section{A B S T R A C T}

This research was carried out at SD Negeri 1 Serongga District of Gianyar. The purpose of writing this school action research is to find out whether academic supervision and managerial supervision can improve the ability of teachers at SD Negeri 1 Serongga, in implementing the learning process using the Mastery Learning model. The data collection method is observation. The data analysis method is descriptive for quantitative data. The results obtained from this study are that clinical supervision can improve the ability of teachers in implementing the learning process using the Mastery Learning learning model. This is evident from the results obtained in Cycle I increasing the average to 80.00 from the initial data and in Cycle II rising the average is 87.1 of Cycle I. The conclusions obtained from this study are academic supervision and managerial supervision can improve the ability of teachers in implementing the learning process using the learning model Mastery Laerning. 


\section{Pendahuluan}

Pendidikan merupakan suatu proses di mana pengalaman dan informasi diperoleh sebagai hasil belajar, yang mencakup pengertian dan penyesuaian diri dari pihak peserta didik terhadap rangsangan yang diberikan kepadanya menuju ke arah pertumbuhan dan perkembangan. Dengan demikian, pendidikan di sekolah dipengaruhi oleh beberapa faktor antara lain: guru, metode/pendekatan/model pembelajaran, kurikulum, media pengajaran, dan peserta didik. Dalam rangka meningkatkan mutu pendidikan di Indonesia diperlukan upaya yang serius untuk meningkatkan kualitas guru. Seorang guru memiliki peran yang paling besar dalam upaya inovasi serta peningkatan mutu pendidikan melalui inovasi dalam proses pembelajaran. Peningkatan mutu pendidikan dapat dimulai dengan meningkatkan mutu guru dalam mengajar dan berprilaku profesional. Berbagai penataran dan pelatihan guru menjadi salah satu bentuk dari upaya tersebut walaupun kurang membekas dalam keseharian aktivitas guru. Hal inilah yang mendasari perlunya perbaikan yang menitikberatkan kepada kondisi nyata di lapangan, mulai dari kondisi di kelas, sekolah, dan guru. Pelaksanaan sertifikasi guru sebagai amanat dari Undangundang (UU) Nomor 14 Tahun 2005 tentang Guru dan Dosen diharapkan berperan dalam peningkatan kualitas pendidikan (Yamin, 2016).

Menurut Undang-Undang Sistem Pendidikan Nasional No.20 Tahun 2003 pasal 1 butir 1, pendidikan adalah: "usaha sadar dan terencana untuk mewujudkan suasana belajar dan proses pembelajaran agar peserta didik secara aktif mengembangkan potensi dirinya untuk memiliki kekuatan spiritual keagamaan, pengendalian diri, kepribadian, kecerdasaan, akhlak mulia, serta keterampilan yang diperlukan dirinya, masyarakat, bangsa dan Negara." Pendidikan nasional bertujuan: "untuk mengembangkan potensi peserta didik agar menjadi manusia yang beriman dan bertakwa kepada Tuhan Yang Maha Esa, berakhlak mulia, cakap, kreatif, mandiri, dan menjadi waarga Negara yang demokratis serta bertanggung jawab" (UU Sisdiknas No. 20 tahun 2003 pasal 3). Pengertian secara khusus, karakter adalah nilai-nilai yang khas baik (tahu nilai kebaikan, mau berbuat baik, nyata berkehidupan baik, dan berdamak baik terhadap lingkungan) yang terpatri dalam diri dan terwujud dalam perilaku. Dalam hubungannya dengan pendidikan, pendidikan karakter dapat dimaknai sebagai pendidikan nilai, pendidikan budi pekerti, pendidikan moral, pendidikan watak, yang bertujuan mengembangkan kemampuan siswa untuk memberikan keputusan baik buruk, memelihara kebaikan, mewujudkan dan menebar kebaikan dalam kehidupan sehari-hari dengan sepenuh hati. Pendidikan karakter berpijak dari karakter dasar manusia, yang bersumber dari nilai moral universal (bersifat absolut) sebagai pengejawantahan nilai-nilai agama yang biasa disebut the golden rule. Pendidikan karakter dapat memiliki tujuan yang pasti, apabila berpijak dari nilai-nilai karakter dasar tersebut. Menurut para ahli psikolog, beberapa nilai karakter dasar tersebut adalah: cinta kepada (Setiawati, 2017).

Cara pembelajran guru yang terus-menerus menggunakan model pembelajaran konvensional harus segera diakhiri menggunakan dunia sudah berkembang begitu pesar dan maju. Kebiasaan guru mengajar dengan sistem lama harus segera mendapat penanganan oleh kepala sekolah. Guru-guru harus berupaya melakukan pembelajaran menggunakan model-model pembelajaran yang didasari teori-teori yang benar. Tidak terbantahkan lagi bahwa kepala sekolah harus mampu meningkatkan kemampuan guru melaksanakan proses pembelajaran. Tugas kepala sekolah dalam hal ini adalah tugas wajib untuk semua kepala sekolah, sehingga penelitian yang dilakukan bisa saja sama dalam meningkatkan proses pembelajaran namun pada subjek dan tempat yang berbeda.

Kompetensi guru diartikan sebagai penguasaan terhadap suatu tugas (mengajar dan mendidik), keterampilan, sikap, dan apresiasi yang diperlukan untuk menunjang keberhasilan proses pembelajaran yang dilakukannya. Dengan demikian, kompetensi yang dimiliki oleh setiap guru akan menunjukkan kualitas guru yang sebenarnya. Kompetensi tersebut akan diwujudkan dalam bentuk penguasaan ketrampilan, pengetahuan maupun sikap profesional dalam menjalankan tugas dan fungsi sebagai guru. Menurut Wahyudi (2012) guru profesional adalah guru yang mampu mengelola dirinya sendiri dalam melaksanakan tugastugasnya sehari-hari. Profesionalisme yang dimaksud oleh mereka adalah satu proses yang bergerak dari ketidaktahuan menjadi tahu, dari ketidakmatangan menjadi matang. Sedangkan menurut Glickman dalam Bafadal yang menegaskan bahwa seseorang akan bekerja secara profesioanl bilaman orang tersebut memiliki kemampuan profesional bilamana memiliki kemampuan tinggi dan motivasi kerja tinggi.

Kompetensi pada dasarnya menunjukkan kepada kecakapan atau kemampuan untuk mengerjakan suatu pekerjaan. Dan kompetensi juga merupakan suatu sifat (karakteristik) orang-orang (kompetensi) ialah yang memiliki kecakapan, daya (kemampuan), otoritas (kewenangan), kemahiran (keterampilan), pengetahuan, dan untuk mengerjakan apa yang diperlukan (Fitriani, 2017).

GURU adalah suatu sebutan bagi jabatan, posisi, dan profesi bagi seseorang yang mengabdikan dirinya dalam bidang pendidikan melalui interaksi edukatif secara terpola, formal, dan sistematis. Dalam 
UU R.I. Nomor 14 Tahun 2005 tentang guru dan dosen pada bab I pasal 1 dinyatakan bahwa: Guru adalah pendidik profesional dengan tugas utama mendidik, mengajar, membimbing, mengarahkan, melatih, menilai, dan mengevaluasi peserta didik pada pendidikan anak usia dini jalur pendidikan formal, pendidikan dasar, dan pendidikan menengah. (Redaksi Sinar Grafika, 2009:3)

Guru yang profesional akan tercermin dalam penampilan pelaksanaan pengabdian tugas-tugas yang ditandai dengan keahlian, baik dalam materi maupun metode. Di samping keahliannya, sosok guru profesional ditunjukkan melalui tanggung jawabnya dalam melaksanakan seluruh pengabdiannya. Guru profesional hendaknya mampu memikul dan melaksanakan tanggung jawabnya sebagai guru kepada peserta didik, orang tua, masyarakat, bangsa, negara, dan agamanya. Sebagai pengajar atau pendidik, guru merupakan salah satu faktor penentu keberhasilan setiap upaya pendidikan. Itulah sebabnya setiap adanya inovasi pendidikan, khususnya dalam kurikulum dan peningkatan sumber daya manusia yang dihasilkan dari upaya pendidikan, selalu bermuara pada faktor guru. Hal ini menunjukkan bahwa betapa eksisnya peran guru dalam dunia pendidikan. Guru menjadi faktor yang menentukan mutu pendidikan karena guru berhadapan langsung dengan para peserta didik dalam proses pembelajaran di kelas. Di tangan guru, mutu dan kepribadian peserta didik dibentuk. Karena itu, perlu sosok guru kompeten, bertanggung jawab, terampil, dan berdedikasi tinggi. Guru adalah kurikulum berjalan. Sebaik apa kurikulum dan sistem pendidikan yang ada tanpa didukung oleh kemampuan guru, semuanya akan siasia. Guru berkompeten dan bertanggung jawab, utamanya dalam mengawal perkembangan peserta didik sampai ke suatu titik maksimal. Tujuan akhir seluruh proses pendampingan guru adalah tumbuhnya pribadi dewasa yang utuh. Seiring dengan kemajuan teknologi informasi yang begitu pesat, guru tidak lagi sekedar bertindak sebagai penyaji informasi. Guru juga harus mampu bertindak sebagai fasilitator, motivator, dan pembimbing yang lebih banyak memberikan kesempatan kepada peserta didik untuk mencari dan mengolah sendiri informasi (Uno, 2009:16-17). Dengan demikian, guru juga harus senantiasa meningkatkan keahliannya dan senantiasa mengikuti perkembangan ilmu pengetahuan dan teknologi sehingga ia mampu menghadapi berbagai tantangan. Perkembangan dunia pendidikan yang sejalan dengan kemajuan teknologi dan globalisasi yang begitu cepat perlu diimbangi oleh kemampuan pelaku utama pendidikan, dalam hal ini guru. Bagi sebagian guru, menghadapi perubahan yang cepat dalam pendidikan dapat membawa dampak kecemasan dan ketakutan. Perubahan dan pembaruan pada umumnya membawa banyak kecemasan dan ketidaknyamanan. Implikasi perubahan dalam dunia pendidikan, bukan perkara mudah, karena mengandung konsekwensi teknis dan praksis, serta psikologis bagi guru. Misalnya, perubahan kurikulum atau perubahan kebijakan pendidikan. Perubahan itu tidak sekedar perubahan struktur dan isi kurikulum. Atau sekedar perubahan isi pembelajaran, tetapi perubahan yang menuntut perubahan sikap dan perilaku dari para guru. Misalnya, perubahan karakter, mental, metode, dan strategi dalam pembelajaran (Shabir U, 2015).

Tugas utama kepala sekolah adalah menagwasi dan sekaligus meningkatkan kemampuan guru dalam melaksanakan proses pembelajaran. Kegiatan ini adalah tugas utama para kepala sekolah mengingat para guru biasanya lebih senang mengajar tanpa persiapan dan tanpa belajar terlebih dahulu. Senangnya guru-guru mengajar tanpa persiapan apabila terus dibiarkan akan menjadi-jadi dan semakin hari akan semakin menjadi kebiasaan yang kurang baik.

Sebagai kepala sekolah harus betul-betul memperhatikan apakah pembelajaran itu berkualitas atau tidak, apabila tidak berkualitas maka hal tersebut akan berbahaya terhadap mutu pendidikan. Masyarakat akan merasa senang apabila melihat guru rajin mengajar, entah apa yang diajar, apakah pembelajaran itu berkualitas atau tidak, tidaklah menjadi masalah. Tetapi bagi kepala sekolah dan dunia pendidikan secara umum masalah kebenaran pembelajaran perlu menjadi perhatian yang penting. Oleh karenanya sebagai kepala sekolah mesti giat untuk melakukan supervisi.

Peraturan-peraturan pemerintah maupun peraturan-peraturan menteri menegaskan agar kualitas pembelajaran terus ditingkatkan dengan tujuan agar peningkatan mutu pendidikan terus bisa ditingkatkan. Usaha ini tidak gampang untuk dilakukan. Untuk bisa melakukannya, sebagai kepala sekolah yang bertugas mensupervisi guru harus betul-betul paham dengan cara supervisi dan merinci kemampuan ilmu lainnya yang berhubungan dengan supervisi akademi dan supervisi manajerial.

Adanya suatu permasalahan yang kurang baik dan sudah terjadi berlarut-larut di SD Negeri 1 Serongga adalah rendahnya kemampuan guru untuk melaksanakan proses pembelajaran sesuai hasil supervisi yang dilakukan sebelumnya yaitu baru mencapai rata-rata 73,7. Hal ini memicu peneliti untuk berupaya memecahkan masalah yang ada melalui sebuah penelitian yaitu Penelitian Tindakan Sekolah.

Kemampuan guru-guru melaksanakan proses pembelajaran belum memadai, tidak memiliki bukubuku teks sesuai yang diharapkan Depdiknas. Mereka belum betul-betul membaca landasan-landasan hukum yang mengacu pada aturan-aturan yang ada. Mereka masih berpola lama yaitu menunggu perintah dan menunggu petunjuk-petunjuk yang akan diberikan secara gratis. Mereka masih belum mengetahui batasan-batasan yang ada dalam Standar Proses tersebut, tujuan-tujuan yang ada, komponen-komponen 
pendukungnya, esensi Standar Proses, elemen-elemen pokok Standar Proses serta langkah-langkah pembelejaran sesuai Permen tersebut.

Berdasarkan fakta dan data yang diperoleh dari hasil pengawasan tahun sebelumnya berupa kelemahan-kelemahan guru dalam melaksanakan proses pembelajaran yang ditindaklanjuti dengan pengecekan ulang kemampuan mereka pada awal tahun pelajaran 2017/2018 menggunakan lembar observasi penilaian proses belajar mengajar, ternyata hasilnya cukup rendah. Oleh karenanya sesegera mungkin mesti dilakukan upaya-upaya untuk melakukan perbaikan. Pendidikan akan berjalan sangat lamban yang diakibatkan oleh keadaan lapangan yang seperti itu dan bila tersebut dibiarkan saja sedemikian rupa maka pendidikan akan semakin terpuruk. Oleh karenanya timbullah pemikiranpemikiran untuk dapat memecahkan masalah ini dengan menggunakan gabungan supervisi individual dengan supervisi akademik dan supervisi manajerial untuk menyelesaikan permasalahan yang ada.

\section{Metode}

Penelitian yang dilakukan termasuk jenis penelitian tindakan. Penelitian tindakan ini terfokus pada penelitian tindakan sekolah. Salah satu contoh penelitian tindakan adalah desain yang dibuat oleh Ebbut (dalam Sukidin, dkk., 2002) seperti terlihat pada gambar berikut.

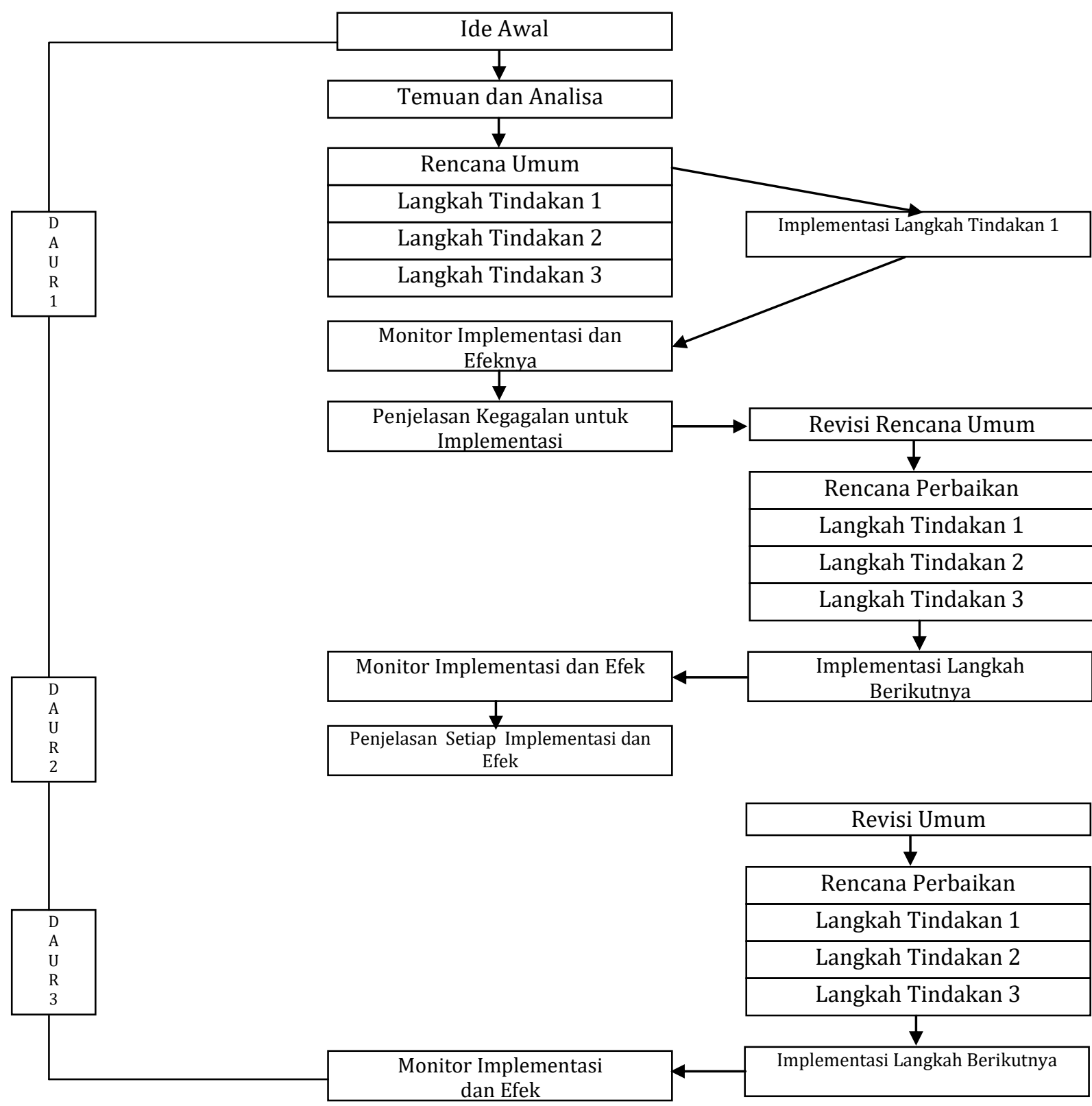

Gambar 1. Desain Penelitian Tindakan Model Ebbut 
Disain yang diberikan oleh Ebbut di atas siklusnya sampai 3. Namun dalam penelitian ini hanya digunakan dua siklus dan mengikuti model penelitian yang diberikan oleh Direktorat Jendral Peningkatan Mutu Pendidik dan Tenaga Kependidikan (2008) yang langkah-langkahnya dapat dilihat pada gambar berikut.

Penelitian ini dilaksanakan di kepada guru-guru SD Negeri 1 Serongga yang berjumlah 10 orang. Sedangkan Objeknya adalah peningkatan kemampuan guru-guru dalam melaksanakan proses pembelajaran.

Metode yang digunakan untuk mengumpulkan data adalah mengikuti langkah-langkah yang digunakan dalam supervisi klinik. Untuk menguji hipotesis penelitian ini dicocokan dengan indikatorindikator keberhasilan penelitian yaitu pengisian lembar observasi penelitian tugas guru. Apabila indikator indikator keberhasilan belum tercapai, maka penelitian ini belum bisa dikatakan berhasil ,dan dilanjutkan ke proses berikutnya, apabila hasil yang diperoleh sudah memenuhi kriteria keberhasilan penelitian, maka penelitian ini tidak dilanjutkan ke siklus berikutnya.

Indikator keberhasilannya adalah naiknya perolehan skor dari fase awal ke siklus I dan ke siklus II. Indikator keberhasilan yang diusulkan adalah pada siklus I mencapai rata-rata 80 dan pada siklus II diharapkan kemampuan guru-guru sudah mencapai minimal 86.

\section{Hasil Dan Pembahasan}

Dalam pelaksanaan proses pembelajaran ada hal-hal penting dalam tersebut seperti: buku teks yang digunakan adalah buku-buku yang sudah disyahkan oleh Departemen Pendidikan, rasio buku teks adalah: 1: per satu mata pelajaran, selain buku teks pelajaran, guru juga boleh menggunakan buku panduan, buku pengayaan, buku referensi dan sumber lainnya serta buku-buku yang ada di perpustakaan sekolah. Dalam pengelolaan proses pembelajaran, guru harus melakukan pengelolaan kelas dengan baik seperti: tempat duduk siswa, suara guru, tutur kata guru, materi yang digunakan, ketertiban, kedisiplinan kelas, penguatan, umpan balik, penghargaan terhadap pendapat siswa, pakaian guru yang rapi, sopan, bersih, penyampaian silabus pada awal semester serta memulai dan mengakhiri proses sesuai waktu yang dijadwalkan.

Deskripsi yang dapat disampaikan untuk perolehan data awal sebagai indikator yang dituntut yaitu minimal guru mampu mencapai ketuntasan belajar dengan nilai sama atau melebihi Ketuntasan namun pada data awal guru-guru SD Negeri 1 Serongga masih jauh dari harapan. Indikator keberhasilan pada penelitian ini yaitu guru-guru diharapkan mampu meraih nilai kuantitatif A atau rata-rata berada pada rentang antara 86-100. Data yang diperoleh menunjukkan nilai klaksikal yang diperoleh sebesar 73,7 dengan rata-rata hanya mencapai 73,7. Rata-rata yang diperoleh berada antara rentang 66-75 ini artinya nilai kuantitatif yang diperoleh adalah C (Cukup). Pada data ini tidak ada guru yang mendapat nilai kuntitatif A, 1 Guru mendapat tergolong nilai kuantitatif B, 2 orang guru memperoleh nilai C dan sisanya memperoleh nialau D. Data tersebut menunjukkan rendahnya kemampuan guru di SD Negeri 1 Serongga dalam melaksanakan pembelajaran. Kekurangan yang ada adalah akibat proses pembelajaran yang dilakukan oleh guru masih bersifat konvensional. Kelebihannya adalah peneliti sebagai pengawas telah giat melakukan supervisi secara maksimal.

Perkembangan kemampuan guru pada siklus I adalah ada 3 orang guru yang memperoleh niali A, 5 orang guru yang memperoleh nilai B, dan sisanya adalah memperoleh nilai C. Nilai klasikal yang diperoleh adalah 800 dengan rata-rata mencapai 80,00 dengan kualifikasi B yang berada pada rentand 76-85. Data tersebut menunjukkan nilai yang diperoleh sudah mengalami peningkatan namun belum maksimal dan perlu dilanjutkan dengan tndakan berikutnya.

Perkembangan kemampuan guru pada siklus II adalah mengalami peningkatan yang signifikan. Ada 8 guru yang memperoleh kualifikasi nilai A, dan sisanya 2 orang guru memperoleh kualifikasi nilai B. Nilai klaksikal yang diperoleh mencapai 871 dengan rata-rata 87,1 dengan kualifikasi nilai A. Data tersebut menunjukkan proses pembelajaran sudah berjalan maksimal karena semua guru sudah mampu mencapai kriteria usulan kinerja yang diharapkan yaitu nilai rata-rata 80 dengan kualifikasi klaksikan antara rentang 86-100 atau A (amat baik) sehingga penelitian ini tidak perlu dilanjutkan dengan tndakan berikutnya.

Hasil penelitian yang diperoleh menunjukkan kenaikan kemampuan guru dari awal, siklus I dan siklus II. Hasil awal dengan rata-rata 73,7 pada siklus I meningkat menjadi 80,00 , dan pada siklus II meningkat menjadi 87,1.

Hasil awal menunjukkan baru tidak ada guru guru memperoleh nilai antara 86-100-85 dengan kriteria amat baik., pada siklus I kemampuan guru meningkat sehingga 1 guru memperoleh nilai dengan kriteria amat baik. Pada siklus II juga terjadi kenaikan. Dari 3 guru pada siklus I baru memperoleh nilai 
antara 86-100, pada siklus II meningkat menjadi 8 guru dari 10 guru memperolen nilai antara 86-100 dengan kriteria amat baik.

Dari data yang dapat diambil poin-poin penting yaitu: pada kenaikan di siklus I, kenaikan tersebut belum mencapai kriteria usulan kinerja yang diharapkan yaitu mencapai nilai rata-rata klaksikal 86, sehingga penelitian masih perlu untuk dilanjutkan, sedangkan pada akhir siklus II, perolehan nilai guruguru sudah melebihi usulan kriteria keberhasilan penelitian sehingga pada tahap ini penelitian tidak perlu lagi untuk dilanjutkan karena telah mencapai batas kriteria kinerja yang diusulkan.

Untuk dapat lebih gampang melihat peningkatan kemampuan guru-guru dalam melaksanakan proses pembelajaran yang baik, di bawah ini disampaikan tabel ringkasan peningkatan kemampuan mereka. Tabel ini sekaligus untuk menjawab rumusan masalah yang diajukan.

Tabel 1. Ringkasan Peningkatan Kemampuan Guru-guru Melaksanakan Proses Pembelajaran

\begin{tabular}{|c|c|c|c|c|c|c|}
\hline \multirow[b]{3}{*}{$\begin{array}{l}\text { No Subjek } \\
\text { Penelitian }\end{array}$} & \multicolumn{6}{|c|}{ Peningkatan Kemampuan Guru-guru Melaksanakan Proses Pembelajaran } \\
\hline & \multicolumn{3}{|c|}{ Akhir Siklus I } & \multicolumn{3}{|c|}{ Akhir Siklus II } \\
\hline & $\begin{array}{l}\text { Pening- } \\
\text { katan rata- } \\
\text { rata }\end{array}$ & $\begin{array}{l}\text { Pening- } \\
\text { katan per- } \\
\text { olehan } \\
\text { skor }\end{array}$ & $\begin{array}{l}\text { Pening- } \\
\text { katan } \\
\text { persen- } \\
\text { tase }\end{array}$ & $\begin{array}{l}\text { Pening- } \\
\text { katan rata- } \\
\text { rata }\end{array}$ & $\begin{array}{l}\text { Pening- } \\
\text { katan per- } \\
\text { olehan } \\
\text { skor }\end{array}$ & $\begin{array}{l}\text { Pening- } \\
\text { katan } \\
\text { persen- } \\
\text { tase }\end{array}$ \\
\hline 1 & 34 & 70 & $70 \%$ & 35 & 70 & $70 \%$ \\
\hline 2 & 35 & 80 & $80 \%$ & 40 & 80 & $80 \%$ \\
\hline 3 & 35 & 80 & $80 \%$ & 40 & 80 & $80 \%$ \\
\hline 4 & 40 & 86 & $86 \%$ & 43 & 86 & $86 \%$ \\
\hline 5 & 36 & 80 & $80 \%$ & 40 & 80 & $80 \%$ \\
\hline 6 & 36 & 80 & $80 \%$ & 40 & 80 & $80 \%$ \\
\hline 7 & 43 & 90 & $90 \%$ & 45 & 90 & $90 \%$ \\
\hline 8 & 35 & 70 & $70 \%$ & 38 & 76 & $76 \%$ \\
\hline 9 & 33 & 78 & $78 \%$ & 39 & 78 & $78 \%$ \\
\hline 10 & 40 & 86 & $86 \%$ & 43 & 86 & $86 \%$ \\
\hline
\end{tabular}

Hasil penelitian ini sejalan dengan penelitian yang dilakukan oleh Astuti pada tahun 2016 dengan judul Penerapan Supervisi Akademik untuk Meningkatkan Kompetensi Guru dalam Menyusun Administrasi Penilaian di SD Laboratorium UKSW. Hasil penelitian menunjukkan temuan bahwa supervisi akademik dapat meningkatkan kemampuan guru-guru dalam menyusun administrasi penilaian dalam pembelajaran di SD Laboratorium Salatiga sebesar 26,2\%.

Penelitian yang dilakukan oleh Joni, dkk tahun 2016 dengan judul Pelaksanaan Supervisi Manajerial Pengawas Sekolah Pada Sekolah Menengah Atas Swasta di Kota Banda Aceh. Hasil penelitian menunjukkan bahwa: Para pengawas sekolah menyusun program supervisi secara bersama dan dikoordinir oleh Kordinator Pengawas (KORWAS). Program yang disusun sudah mengikuti pedoman dan berorientasi pada hasil supervisi tahun sebelumnya. Supervisi manajerial dilaksanakan melalui kegiatan pra supervisi dan selanjutnya melakukan tiga tahapan kegiatan, yaitu penilaian kinerja kepala para pengelola sekolah, kegiatan pemantauan pada pelaksanaan delapan Standar Nasional Pendidikan (SNP). Sedangkan kegiatan pembinaan mengarahkan para pengelola sekolah agar dapat bekerja sesuai dengan tugas pokok dan fungsinya. Hambatan pelaksanaan supervisi manajerial dari pengawas sendiri dan dari lapangan, yaitu: tingkat pemahaman pengawas belum seragam, sedangkan hambatan dilapangan staf pelaksana adminsitrasi sekolah belum mencukupi. Berdasarkan hasil penelitian disarankan agar pelaksanaan supervisi manajerial dilaksanakan lebih intensif untuk meningkatkan keterampilan kerja tenaga kependidikan.

\section{Simpulan Dan Saran}

Dari data yang diperoleh dapat disimpulkan bahwa: untuk guru-guru di SD Negeri 1 Serongga, ternyata supervisi klinik dapat meningkatkan kemampuan mereka dalam melaksanakan proses pembelajaran dengan baik. Secara ringkasnya analisis kuantitatif sudah membuktikan bahwa kemampuan guru-guru dari awal ke akhir siklus I meningkat baik walaupun ada kategori-kategori yang belum terpenuhi. Kemampuan guru-guru memang betul sudah meningkat setelah dicoba melihat dari validitas internal, ekternal dan reliabilitasnya. Dari reliabilitasnya, para informan sudah diupayakan dipilih orangorang dekat guru-guru untuk ditanyai tentang keberadaan guru-guru. Validitas eksternalnya dicek melalui 
landasan-landasan hukum yang ada, yang sudah dimasukkan dalam perencanaan program di akhir siklus I sedangkan validitas internalnya ditanyakan lewat wawancara dengan kepala sekolah. Bahkan pada siklus I kemampuan guru-guru sudah meningkat. Nilai yang semula rata-rata 73.7 meningkat menjadi 80,00 dan pada akhir siklus II meningkat lagi menjadi 87,1.

Berdasarkan simpulan tersebut maka diberikan saran bahwa: guru hendaknya selalu belajar dan mengikuti perkembangan zaman, sehingga pembelajaran yang diterapkan guru di kelas merupakan pembelajaran yang inovatif dan membuat siswa menjadi senang dalam proses pembelajaran.

\section{Daftar Rujukan}

Ansyori, Ahmad. 2005. Penelitian Tingkat Kepuasan Pasien Peserta Program Jaminan Pemeliharaan Kesehatan (JPK) Terhadap Pelayanan Kesehatan di Pelaksana Pelayanan Kesehatan Tingkat Pertama (PPK Tk. I) PT. Jamsostek (Persero) Se-Medan Raya. www.pamjaki.org/new/download/download.php? file=practice 315 b.pdf.

Arikunto Suharsimi. 1992. Prosedur Penelitian. Jakarta: PT. Rineka Cipta.

Arikunto, Suharsimi, Sukardjono, Supardi. 2006. Penelitian Tindakan Kelas. Jakarta: PT Bumi Aksara

Astuti. Suhandi. 2016. Penerapan Supervisi Akademik untuk Meningkatkan Kompetensi Guru dalam Menyusun Administrasi Penilaian di SD Laboratorium UKSW. Jurnal Pendidikan dan Kebudayaan UKSW Vol 6 No 1.

Azhar, Lalu Muhammad. 1996. Supervisi Klinis. Surabaya: Penerbit Usaha Nasional.

Cogan, Moris L. 1973. Clinical Supervision. Boston: Houghton Mifflin, Co.

Danim, Sudarwan. 2007. Visi Baru Manajmen Sekolah. Jakarta: Bumi Aksara.

Fitriani, Cut. 2017. Kompetensi Profesional Guru Dalam Pengelolaan Pembelajaran Di Mts Muhammadiyah Banda Aceh . Jurnal Magister Administrasi Pendidikan ISSN 2302-0156 Pascasarjana Universitas Syiah Kuala

Joni, Syarwan, dkk. 2016. Pelaksanaan Supervisi Manajerial Pengawas Sekolah Pada Sekolah Menengah Atas Swasta di Kota Banda Aceh. Jurnal Administrasi Pendidikan Pascasarjana Universitas Syiah Kuala Vol 4 No 1.

Setiawat, Nanda Ayu. 2017. Pendidikan Karakter Sebagai Pilar Pembentukan Karakter Bangsa . Jurnal Fakultas Ilmu Sosial Universitas Negeri Medan Tahun 2017 Vol. 1 No. 12017

Shabir U, M. 2015. Kedudukan Guru Sebagai Pendidik: (Tugas Dan Tanggung Jawab, Hak Dan Kewajiban, Dan Kompetensi Guru) . Jurnal Auladuna, Vol. 2 No. 2 Desember 2015: 221-232

Yamin, Monawatidan M.. 2016. Upaya Meningkatkan Hasil Belajar Siswa Melalui Lesson Studypada Penjumlahan Pecahan Di Kelas Iv Sdn Lamsayeun . Jurnal Pesona Dasar Universitassyiah Kuala Vol. 3 No.4, Oktober 2016 